\title{
Implementasi Business Intelligence dalam Peningkatan Kinerja Manajemen Baitul Mal Unisba
}

\author{
Djamaludin ${ }^{1}$, Hirawati Oemar ${ }^{1^{*}}$, Anisa Rachmani ${ }^{1}$ \\ ${ }^{1}$ Fakultas Teknik, Program Studi Teknik Industri, Universitas Islam Bandung \\ Jl. Tamansari no. 1 \\ Kota Bandung, Jawa Barat - Indonesia 40116 \\ Email: djamaludin@unisba.ac.id, ”hirawatio@yahoo.co.id, arachty94@gmail.com
}

\begin{abstract}
ABSTRAK
Baitul Mal Unisba (BMU) sebagai lembaga pengelola Ziswaf dibawah naungan Yayasan Universitas Islam Bandung berupaya terus untuk meningkatkan kinerja manajemen nya dalam upaya menjadi salah satu yang terbaik dalam pengelolaan Ziswaf. Oleh karena itu diperlukan adanya suatu perangkat yang baik dalam pengambilan keputusan dan pengelolaan organisasi berdasarkan data yang terintegrasi. Salah satu perangkat yang dapat digunakan adalah Business Intelligence (BI) yang mencakup penyediaan laporan yang relevan, kartu skor (scorecards), dasbor, analisis multi dimensi, analisis statistik, model, dan atau simulasi kepada pengguna untuk meningkatkan kinerja manajemen. Penelitian ini bertujuan untuk untuk mengembangkan dan mengimplementasikan model $\mathrm{Bl}$ yang tepat dalam pengelolaan Baitul Mal Unisba. Metodologi BI ini diawali dengan melakukan pengamatan terhadap proses pengambilan keputusan dan data/dokumen yang diperlukan. Selanjutnya dilakukan penyusunan evaluasi infrastruktur, analisis bisnis, hingga pembuatan rancangan $\mathrm{Bl}$ dan uji coba implementasi aplikasi BI di BMU. Hasil implementasi BI menunjukkan kemampuan analitik dalam meningkatkan penerimaan dan penyaluran Ziswaf secara tepat.
\end{abstract}

Keywords: Business Intelligence, Kinerja Manajemen, Ziswaf, Pengambilan Keputusan

\section{ABSTRACT}

Baitul Mal Unisba (BMU) as a Ziswaf management institution under the auspices of the Bandung Islamic University Foundation strives to continuously improve its management performance in an effort to become one of the best in Ziswaf management. Therefore, it is necessary to have a good tool in decision making and organizational management based on integrated data. One of the tools that can be used is Business Intelligence (BI) which includes providing users with relevant reports, scorecards, dashboards, multi-dimensional analysis, statistical analysis, models, and/or simulations to improve management performance. This study aims to develop and implement an appropriate $\mathrm{BI}$ model in the management of Baitul Mal Unisba. The BI methodology begins with observing the decision-making process and the required data/documents. Furthermore, the preparation of infrastructure evaluation, business analysis, to the making of $\mathrm{BI}$ designs and trial implementation of $B I$ applications at BMUs. The results of BI implementation show analytic capabilities in increasing Ziswaf revenue and distribution appropriately.

Keywords: Business Intelligence, Management Performance, Ziswaf, Decision Making

\section{Pendahuluan}

Zakat bagi Umat Muslim merupakan Ibadah sosial yang wajib dilakukan dan termasuk dalam lima rukun islam. Indonesia dengan lebih dari 200 juta jiwa jumlah penduduknya beragama Islam, maka zakat, infak, sedekah dan wakaf (Ziswaf) sangat berperan dalam perekonomian di Indonesia, terutama untuk pengentasan kemiskinan dan peningkatan kesejahteraan masyarakat.

Potensi Zakat di Indonesia menurut Baznas (Baznas, 2017) adalah sekitar 217 triliun rupiah, dengan pengumpulan zakat nasional di tahun 2019 (Baznas, 2019) terhitung mencapai 10,2 triliun rupiah 
dengan perbandingan penyaluran zakat berdasarkan bidang program. Tabel 1, memperlihatkan jumlah penyaluran zakat pada beberapa bidang.

Tabel 1. Perbandingan Penyaluran Zakat

\begin{tabular}{|l|r|l|}
\hline \multicolumn{1}{|c|}{ Penyaluran per bidang } & Jumlah Dana (Rp) & \\
\hline Ekonomi & $841,159,855,062$ & 13.5 \\
Pendidikan & $1,201,622,002,187$ & 19.3 \\
Dakwah & $1,553,693,450,575$ & 25.0 \\
Kesehatan & $324,291,528,224$ & 5.2 \\
Sosial Kemanusiaan & $2,296,711,735,408$ & 36.9 \\
Total & $6,218,478,571,455$ & 100.0 \\
\hline
\end{tabular}

Sumber : Statistik Zakat Nasional (2019)

Hal ini menunjukkan masih besarnya potensi pengumpulan ZISWAF oleh Lemabaga atau Badan Amil Zakat yang resmi untuk meningkatkan kesejahteraan masyarakat khususnya umat muslim di Indonesia.

Baitul Maal Unisba (BMU) merupakan lembaga yang mengelola dana dari zakat, infak, sedekah, juga dana wakaf (Ziswaf) serta dana sosial lainnya yang dimiliki oleh Yayasan Universitas Islam Bandung (Unisba). BMU berstatus sebagai unit kerja Yayasan Unisba yang dibentuk berdasarkan Surat Keputusan Pengurus Yayasan Universitas Islam Bandung pada tanggal 16 November tahun 2016 dengan Nomor SK: 295/P-Y-Unisba/SK/11-2016.Program-progam yang dijalankan oleh BMU antara lain Beasiswa, Dana Talang Pendidikan, Sebar Qur'an Wakaf, tanggap bencana, support madrasah, support dakwah, santunan, dan lain-lain.Penyaluran dana Ziswaf di BMU sekitar $90 \%$ digunakan untuk keperluan beasiswa mahasiswa di Unisba, dengan sumber pendanaan baik internal (infak mahasiswa, dosen dan tenaga kependidikan) maupun eksternal (alumni, sponsor perusahaan).

Dengan semakin besarnya organisasi dan dana yang dikelola / didistribusikan, maka diperlukan adanya suatu perangkat yang baik dalam pengambilan keputusan dan pengelolaan organisasi berdasarkan data yang terintegrasi. Business Intelligence (BI) merupakan perangkat yang dapat digunakan. Business Intelligence $(\mathrm{BI})$ disebut juga Intelijensi Bisnis mencakup penyediaan laporan yang relevan, kartu skor (scorecards), dasbor, peringatan email, kueri yang ditentukan pengguna sebelumnya, kemampuan kueri ad hoc, analisis multi dimensi, analisis statistik, perkiraan, model, dan atau simulasi kepada pengguna bisnis untuk digunakan dalam meningkatkan kinerja manajemen, pendapatan atau mengurangi biaya (Steve Williams, 2016). Proses BI didasarkan pada transformasi data menjadi informasi, kemudian kepada keputusan, dan tindakan (Sharda Ramesh, 2018). Pengembangan Business Intelligence (BI) dibagi menjadi enam tahap yaitu justification, planning, business analysis, design, construction dan deployment (Larissa T. Moss, S. A., 2003).

Saeed Rouhani (2012) telah melakukan penelitian tentang pentingnya pemanfaatan Business Intelligence $(\mathrm{BI})$ dengan pendekatan manajerial (fokus pada perbaikan manajemen pengambilan keputusan), teknikal (fokus pada perangkat pendukung dalam pengambilan keputusan), dan pendekatan nilai tambah (fokus pada kemampuan meningkatkan nilai tambah informasi). Dalam penelitiannya Bernhard Wieder (2015) telah menunjukkan bahwa kualitas manajemen BI memberikan dampak langsung secara positif terhadap kualitas data, kualitas informasi, lingkup solusi $\mathrm{BI}$, dan pengambilan keputusan. Business Intelligence telah di manfaatkan pada instansi pemerintah Kementerian Keuangan RI (Junaedi, Abdillah, \& Yasin, 2020), organisasi seperti Perpustakaan Sekolah (Martono, Sudarto, Rustiana, \& Rahayu, 2013) dan Perguruan Tinggi (Warnars, 2008).

Permasalahan pada penelitian ini adalah bagaimana mengimplementasikan BI sebagai acuan dalam pengambilan keputusan baik rutin, operasional maupun strategis untuk meningkatkan kinerja manajemen Baitul Mal Unisba. Tujuan penelitian ini adalah untuk mengembangkan dan mengimplementasikan model BI yang tepat dalam peningkatan kinerja pengelolaan Baitul Mal, khususnya Baitul Mal Unisba. Urgensi dalam penelitian ini adalah memberikan model BI yang tepat dalam pengelolaan Baitul Mal, khusunya Baitul Mal Unisba. Model BI ini diharapkan dapat membantu dalam pengambilan keputusan berdasarkan data, baik yang bersifat rutin, operasional maupun strategis, sehingga diharapkan dapat meningkatkan kinerja manajemen Baitul Mal. 


\section{Methode}

Metode penelitian dimulai dengan melakukan wawancara dan observasi dengan melakukan penekanan pada proses, makna dan pemahaman melalui kata-kata atau gambar, dan dilanjutkan dengan pengambilan data yang ada di BMU. Tahapan penelitian secara rinci diperlihatkan pada Gambar 1.

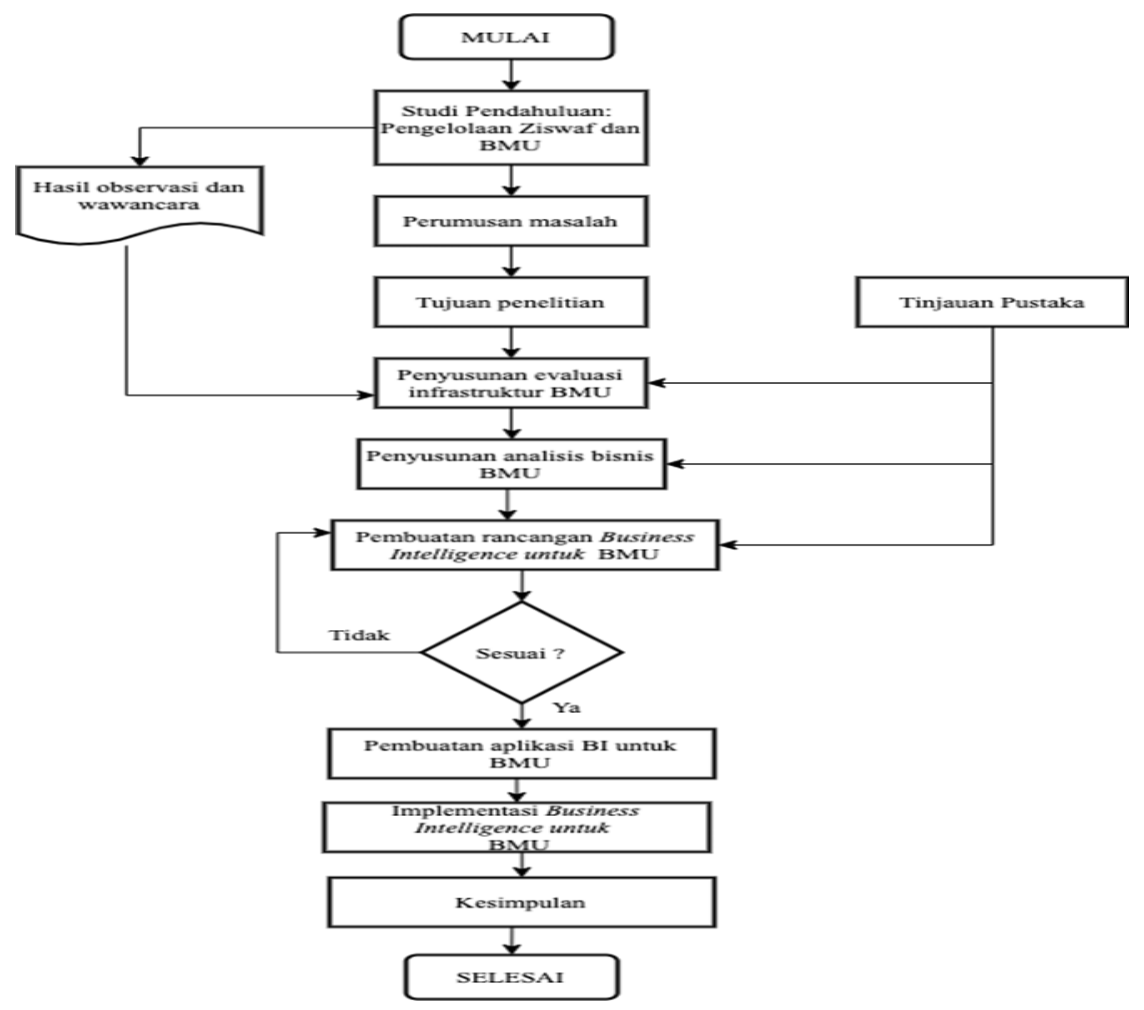

Gambar 1. Metode Penelitian

Adapun penjelasan dari masing-masing tahapan adalah sebagai berikut :

1. Studi pendahuluan; Observasi dan wawancara tentang pengelolaan Ziswaf oleh Baitul Mal Unisba (BMU), serta faktor-faktor yang diperlukan untuk penentuan dan peningkatan kinerja manajemen BMU, dilakukan pada studi pendahuluan ini.

2. Perumusan masalah; Permasalahan yang dihadapi dalam pengambilan-pengambilan keputusan baik yang bersifat rutin, operasional maupun strategis yang dijalankan selama ini, di rumuskan berdasarkan studi pendahuluan

3. Tujuan penelitian; Secara umum, tahap ini merupakan tahap dimana tujuan yang ingin dicapai penelitian ini, ditentukan. Tujuan dari penelitian yang dilakukan adalah untuk mengembangkan dan mengimplementasikan model $\mathrm{BI}$ yang tepat dalam pengelolaan Baitul Mal, khususnya Baitul Mal Unisba.

4. Penyusunan evaluasi infrastruktur BMU; Pada tahap ini melakukan evaluasi terhadap infrastruktur yang dimiliki oleh BMU, meliputi evaluasi infrastruktur teknis yaitu perangkat keras dan perangkat lunak, sistem pada manajemen database dan sistem operasi, komponen jaringan dan penyimpanan meta data, juga evaluasi non teknis pada standar meta data, penamaan data dan model logika data.

5. Penyusunan analisis bisnis BMU; Tahap ini melakukan analisa data, perancangan prototipe aplikasi dan analisa penyimpanan meta data (meta data repositories).

6. Pembuatan rancangan Business Intelligence untuk BMU; Pembuatan rancangan $\mathrm{BI}$ ini meliputi rancangan database, rancangan ETL (Extract/Transform/Load), dan rancangan penyimpanan meta data.

7. Apakah rancangan $\mathrm{BI}$ sesuai dengan kebutuhan $\mathrm{BMU}$; Rancangan $\mathrm{BI}$ yang dibangun harus sesuai dengan kebutuhan BMU berdasarkan analisis bisnis yang telah dilakukan. 
8. Pembuatan Aplikasi BI untuk BMU; Tahap ini melakukan pengembangan ETL, aplikasi BI, Data mining, serta pengembangan penyimpanan meta data.

9. Implementasi BI untuk BMU; Pada tahap ini melakukan implementasi dan evaluasi pemanfaatan BI untuk BMU

10. Kesimpulan; Berdasarkan hasil proses dan implementasi pembuatan BI untuk BMU, kemudian disusun kesimpulan yang merupakan rekomendasi untuk pengembangan Business Intelligence yang sesuai dengan perkembangan organisasi BMU.

\section{Hasil dan Pembahasan}

\subsection{Analisis Data dan Infrastruktur BMU}

Saat ini pengelolaan sistem informasi yang ada di Baitul Maal Unisba, belum terkelola dengan baik dalam suatu sistem yang terstruktur dan terintegrasi. Penginputan dan penyimpanan data dalam format excel yang tidak terstruktur dan tersimpan di masing-masing staf atau pengguna yang berkepentingan, sehingga tidak mampu memberikan input atau data yang baik bagi pengambilan keputusan yang sifatnya situasional, operasional maupun strategis.

Data yang berhasil dihimpun ditunjukan pada Tabel 2 .

Tabel 2. File/data BMU

\begin{tabular}{|c|c|c|c|}
\hline No & Nama File (.xls) & Tabel & Field \\
\hline 1 & $\begin{array}{l}\text { Data Penghimpunan } \\
\text { Tahunan.xls }\end{array}$ & Penghimpunan & $\begin{array}{l}\text { Donatur Internal (jenis donatur dan } \\
\text { tahun donasi) } \\
\text { Donasi Eksternal (jenis donatur dan } \\
\text { tahun donasi) } \\
\text { Total penghimpunan keseluruhan }\end{array}$ \\
\hline 2 & Beasiswa201820.xls & $\begin{array}{l}\text { Penerima beasiswa } 18 \\
\text { Penerima beasiswa } 19 \\
\text { Penerima beasiswa } 20\end{array}$ & $\begin{array}{l}\text { No., nama lengkap, angkatan, npm, } \\
\text { fakultas, jurusan, jalur pendaftaran }\end{array}$ \\
\hline \multirow[t]{6}{*}{3} & Danalainnya.xls & $\begin{array}{l}\text { Dana sosial } 2018 \\
\text { Dana sosial } 2019\end{array}$ & No., tanggal, nama, nominal, kode \\
\hline & & $\begin{array}{l}\text { Kebencanaan } 2018 \\
\text { Kebencanaan } 2019 \\
\text { Kebencanaan } 2020 \\
\end{array}$ & No., tanggal, keterangan, nominal, kode \\
\hline & & $\begin{array}{l}\text { Wakaf } 2019 \\
\text { Wakaf } 2020 \\
\end{array}$ & No., tanggal, nama, nominal, kode \\
\hline & & $\begin{array}{l}\text { Ramadhan } 2019 \\
\text { Ramadhan } 2020 \\
\end{array}$ & No.,tanggal, nama, nominal, kode \\
\hline & & Dana Sosial 2020 & No.,tanggal, nama, nominal, kode \\
\hline & & Qurban 2020 & No.,tanggal, nama, nominal, kode \\
\hline \multirow[t]{2}{*}{4} & Danatalang201820.xls & $\begin{array}{l}\text { PDT } 2018 \\
\text { PDT } 2019 \\
\text { PDT } 2020 \\
\end{array}$ & No.,tanggal, nama, nominal, kode \\
\hline & & $\begin{array}{l}\text { Pinjaman Dana Talang } 18 \\
\text { Pinjaman Dana Talang } 19 \\
\text { Pinjaman Dana Talang } 20 \\
\end{array}$ & No.,tanggal, nama, nominal, kode \\
\hline \multirow[t]{2}{*}{5} & $\begin{array}{l}\text { Rekappenyaluran } 201920 \\
\text {.xls }\end{array}$ & Penyaluran & $\begin{array}{l}\text { Program, tahun (jumlah penerima, } \\
\text { jumlah dana) }\end{array}$ \\
\hline & & Rekap 2019 & $\begin{array}{l}\text { No., jenis penerimaan/pengeluaran, } \\
\text { persentase }\end{array}$ \\
\hline 6 & luran rutin.xls & $\begin{array}{l}2018 \\
2019 \\
2020 \\
\end{array}$ & $\begin{array}{l}\text { No. (kode gaji), kode, nama, bln, jml, } \\
\text { jab, kode zis }\end{array}$ \\
\hline 7. & Kode akun bmu.xls & akun & COA, Pos, Laporan, aktivitas \\
\hline
\end{tabular}

Data dari file yang ada tersebut di atas, akan menjadi input untuk database yang akan dirancang selanjutnya. Infrastruktur sistem informasi yang ada di Baitul Maal belum memadai untuk suatu sistem yang terintegrasi, dikarenakan tidak adanya sistem dan database yang terintegrasi baik berupa client/server ataupun berbasis cloud. 


\subsection{Analisis dan Rancangan Database}

Dari file dan data yang berhasil dihimpun, maka diperlukan transformasi digital dari semula berupa file ms.excel menjadi suatu database yang terintegrasi, yang memudahkan untuk pemasukan dan pengambilan data terpusat. Database menggunakan aplikasi open source MySQL. Gambar 2 memperlihatkan hasil analisis dan rancangan skema database BMU, khusus untuk pengumpulan dan penyaluran Zakat, Infaq dan Sadaqah (ZIS).

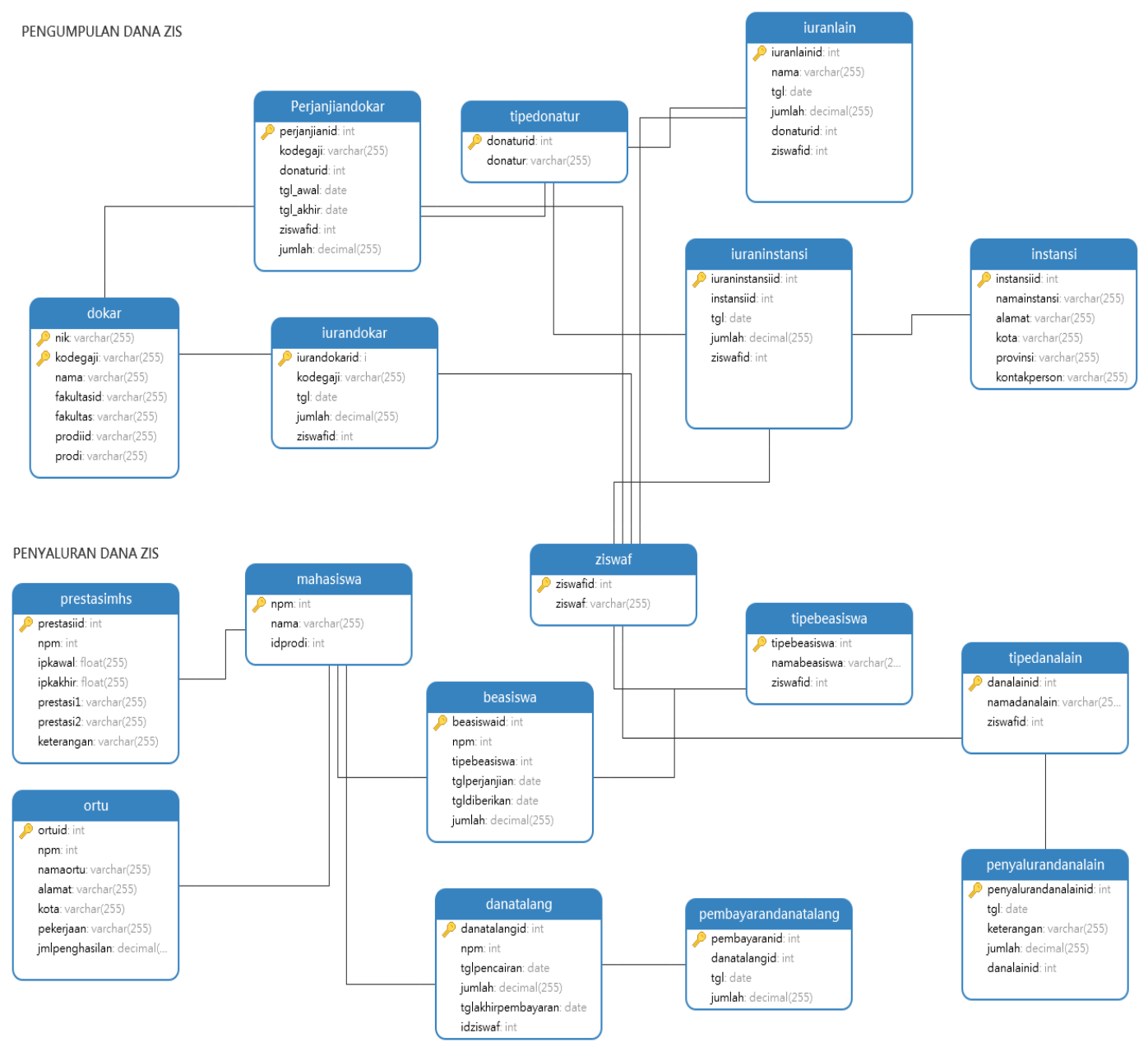

Gambar 2. Rancangan skema database Pengumpulan dan Penyaluran ZIS

\subsection{Analisis dan Rancangan Datawarehouse/ETL}

File seperti terlihat pada Tabel 2 dengan data yang tersebar, tidak terstruktur, tidak konsisten memerlukan proses untuk menjadikannya suatu data yang baik dan tersimpan dalam database terpusat. Oleh karena itu diperlukan proses ETL yang mampu untuk mengekstraksi, mentransformasi, dan menyimpan nya dalam bentuk database yang baik dan terpusat. Proses ETL ini dilakukan dengan bantuk aplikasi Easymorph yang mampu memilah, menambahkan, menyatukan dari semula file ms.excel kedalam database mysql. Datawarehouse yang didapat akan digunakan untuk membuat presentasi baik yang bersifat laporan interaktif, sementara ataupun statis, dengan menggunakan aplikasi PowerBI. Gambar 3 menunjukkan skema proses ETL dan Datawarehouse untuk pengumpulan dan penyaluran ZIS di Baitul Maal Unisba. 


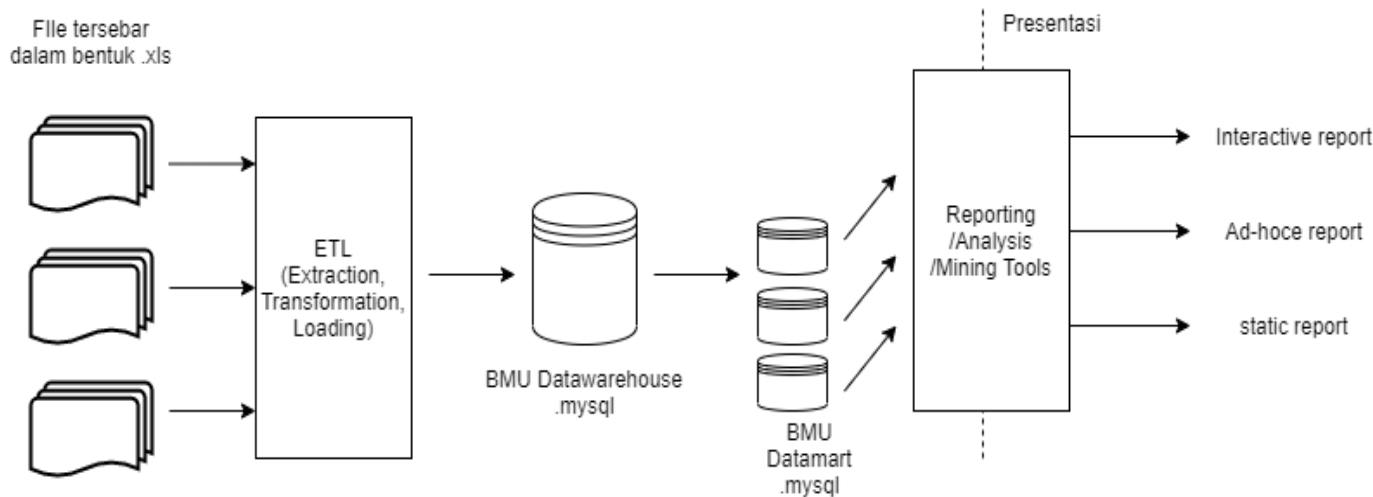

Gambar 3. Skema datawarehouse/ETL Pengumpulan dan Penyaluran ZIS

\subsection{Analisis Proses Bisnis Penghimpunan dan Penyaluran ZIS BMU}

Proses bisnis penghimpunan dan penyaluran ZIS Baitul Maal Unisba di tunkukkan pada Gambar 4 dan Gambar 5.

PENGHIMPUNANZIS

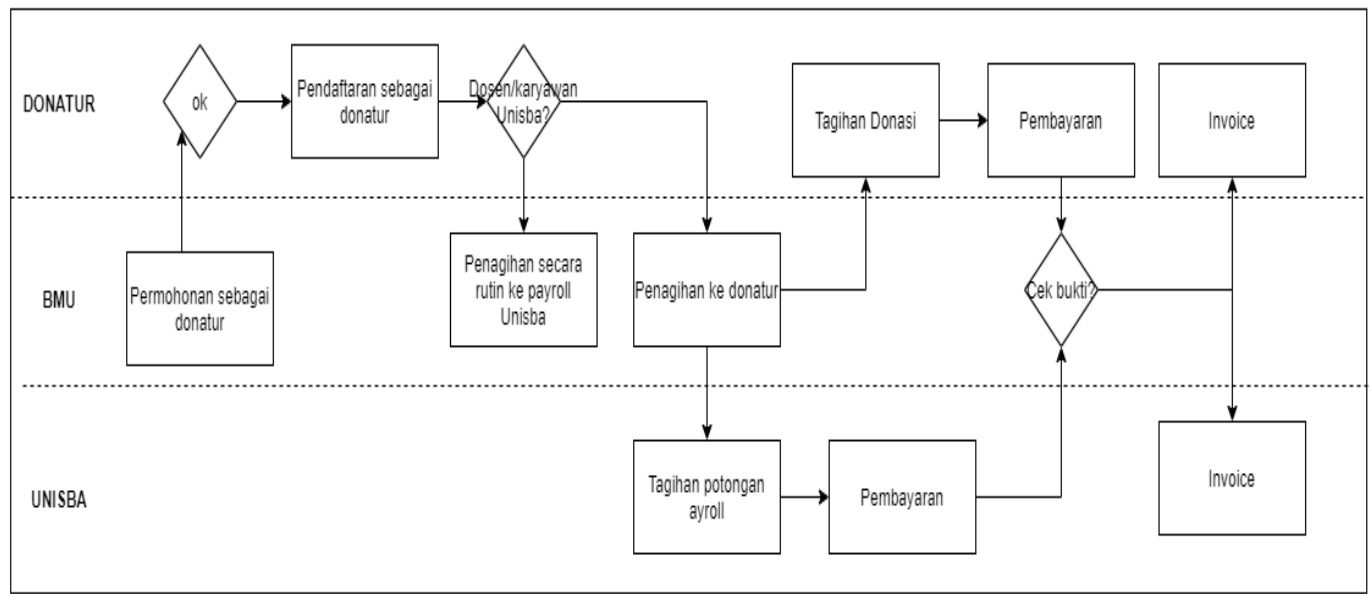

Gambar 4. Proses Bisnis Penghimpunan ZIS

PENYALURAN ZIS

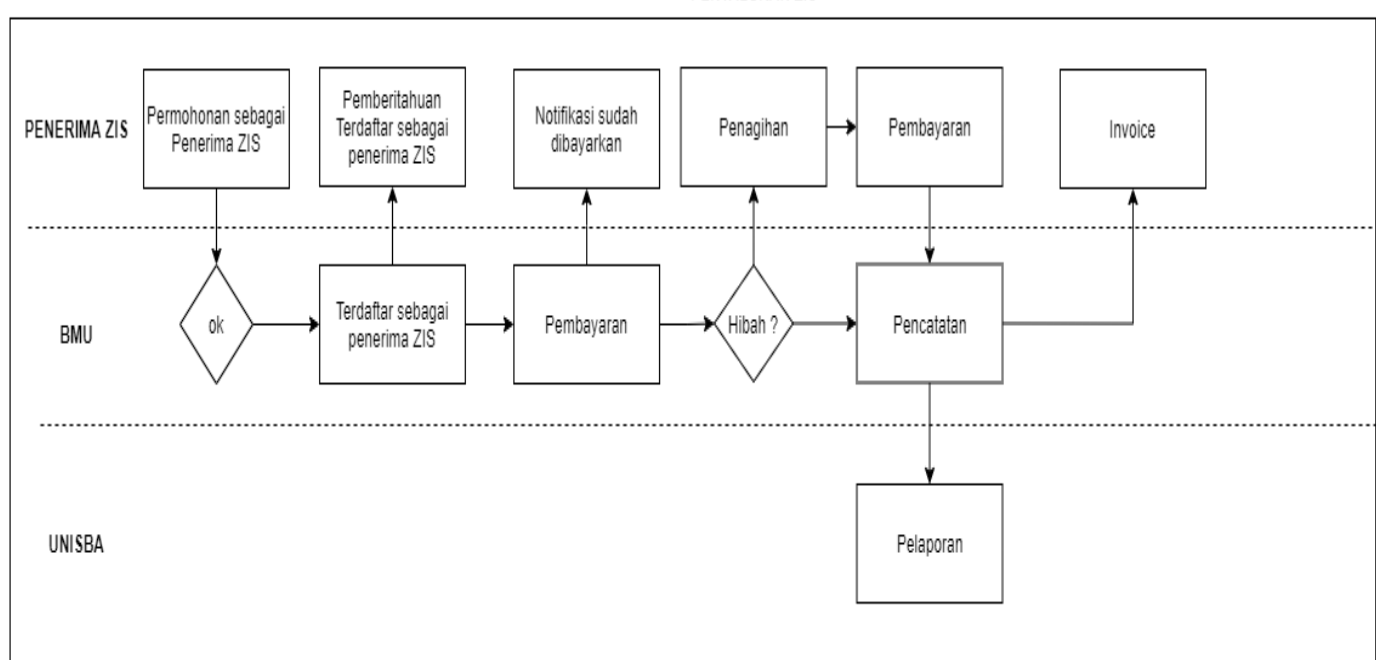

Gambar 5. Proses Bisnis Penyaluran ZIS 


\subsection{Aplikasi Business Intelligence}

Aplikasi Business Intelligence pada penerimaan dana ZIS Baitul Maal Unisba di perlihatkan pada Gambar 6 sampai dengan Gambar 11, dan Penyaluran dana di tunjukkan pada Gambar 12 sampai dengan Gambar 15.

\subsubsection{Penerimaan ZIS BMU}

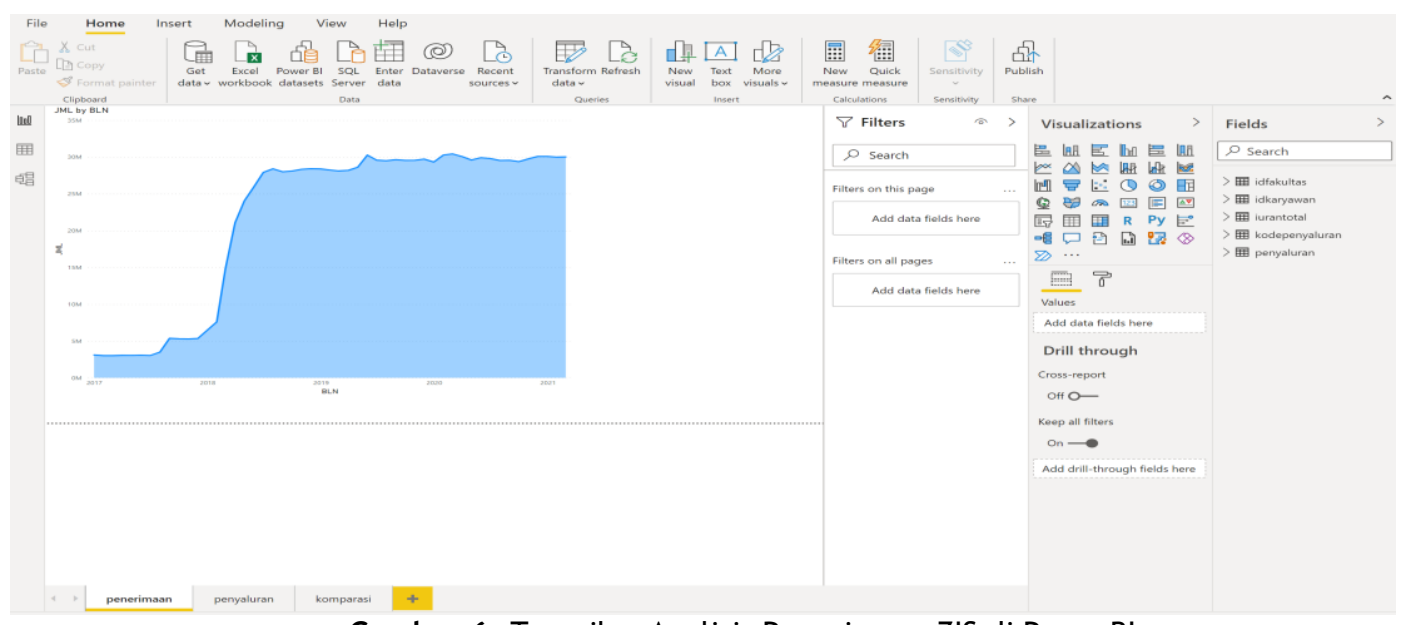

Gambar 6. Tampilan Analisis Penerimaan ZIS di PowerBI

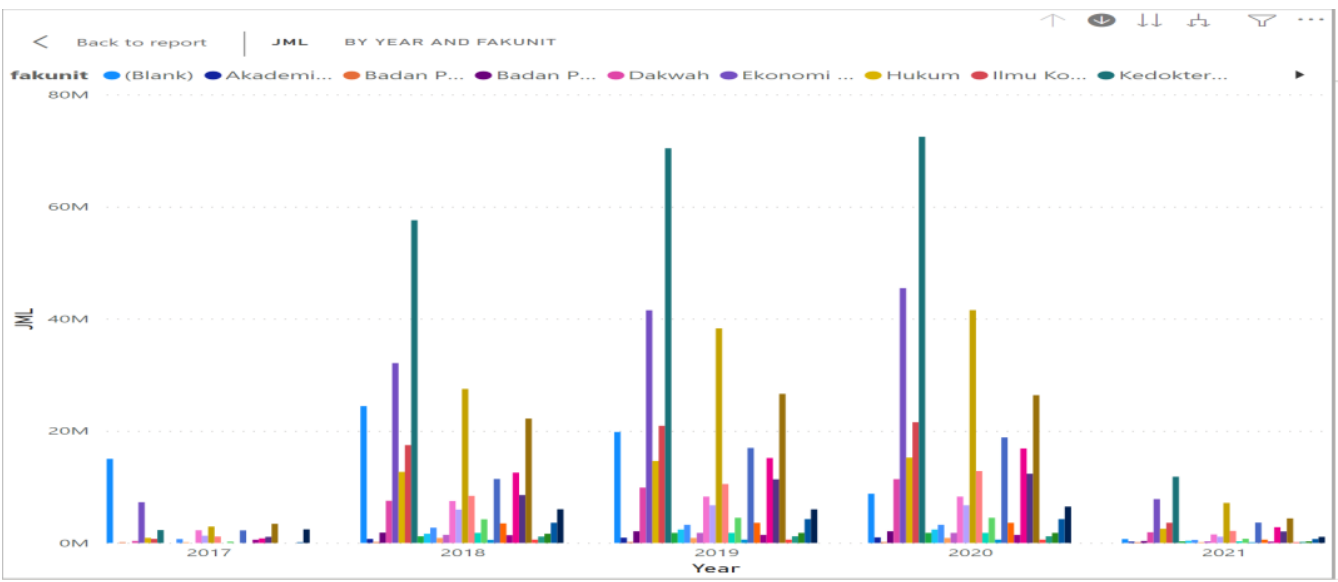

Gambar 7. Penerimaan internal by year and fakultas 1

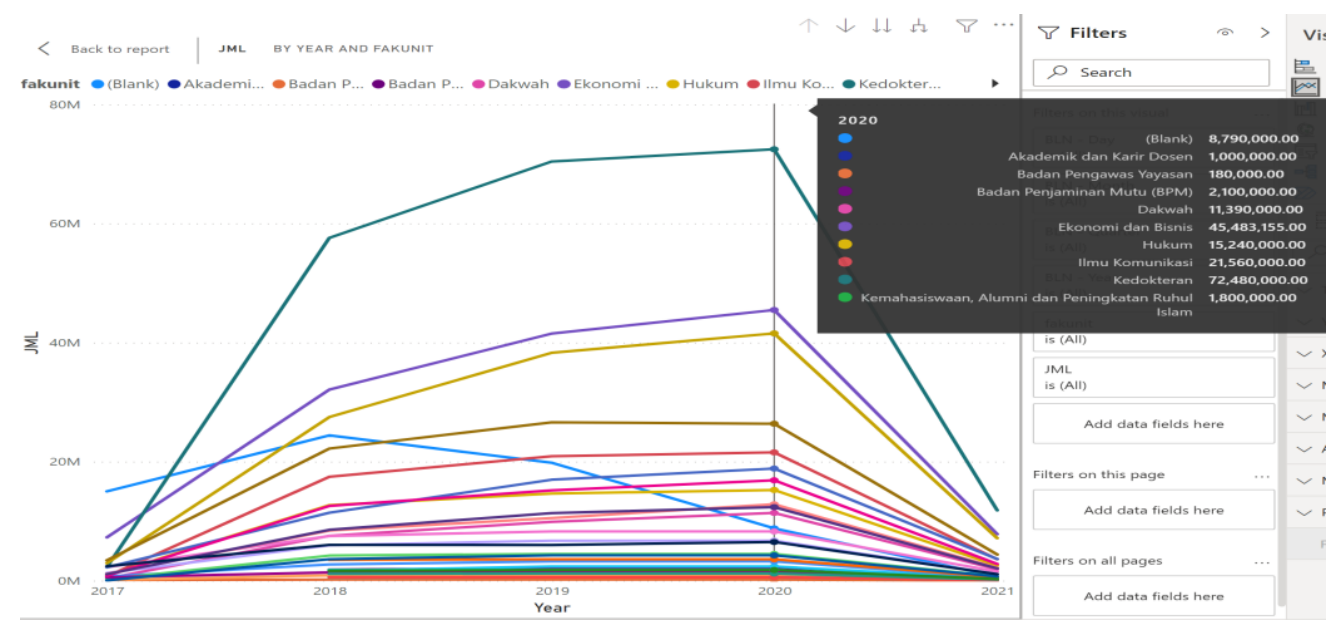

Gambar 8. Penerimaan internal by year and fakultas 2 


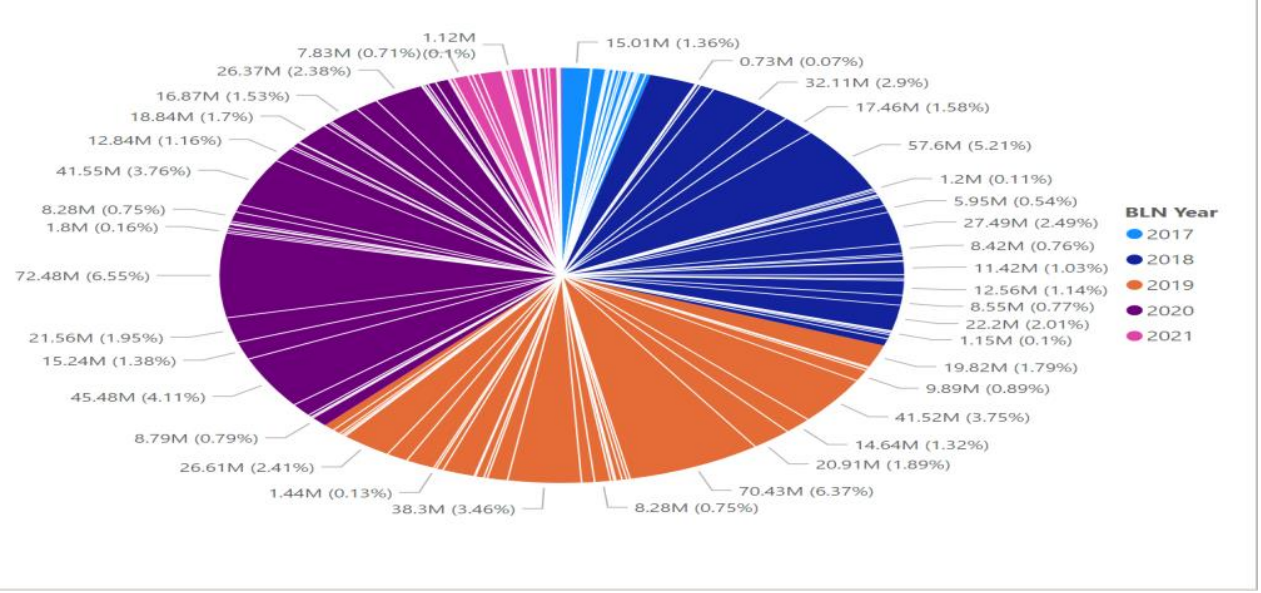

Gambar 9. Penerimaan internal by jumlah and fakultas

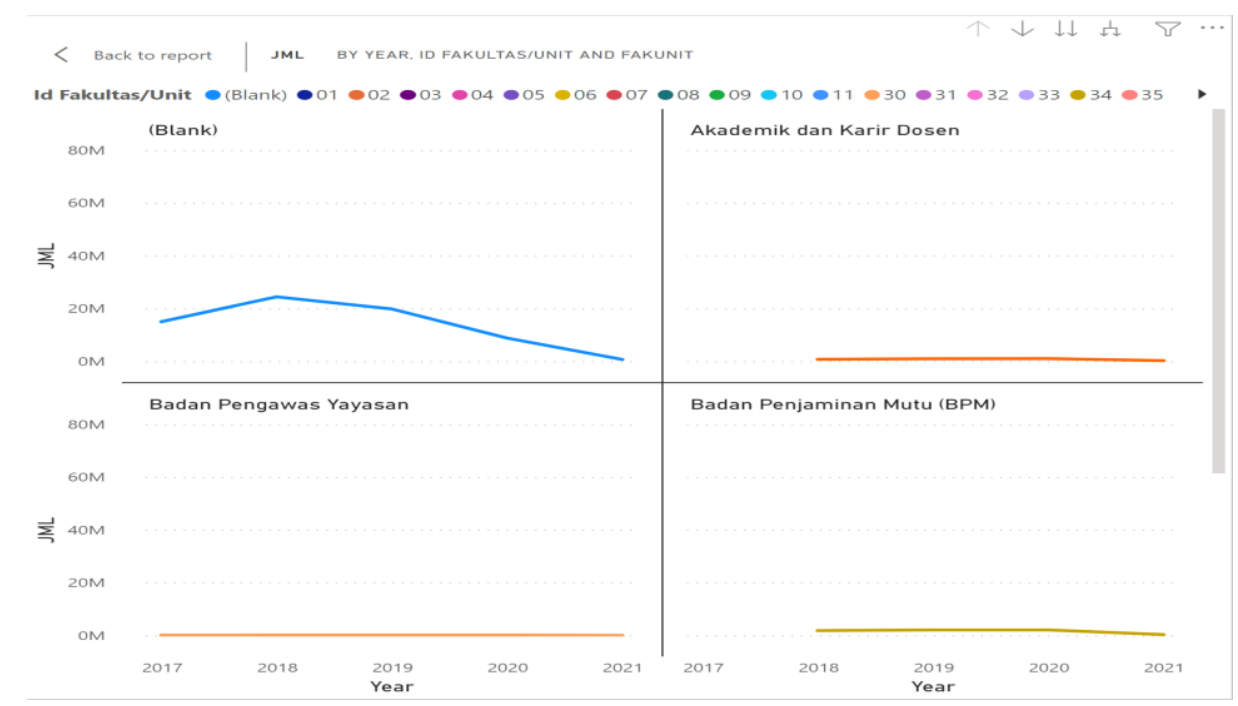

Gambar 10. Penerimaan internal by year and fakultas 1

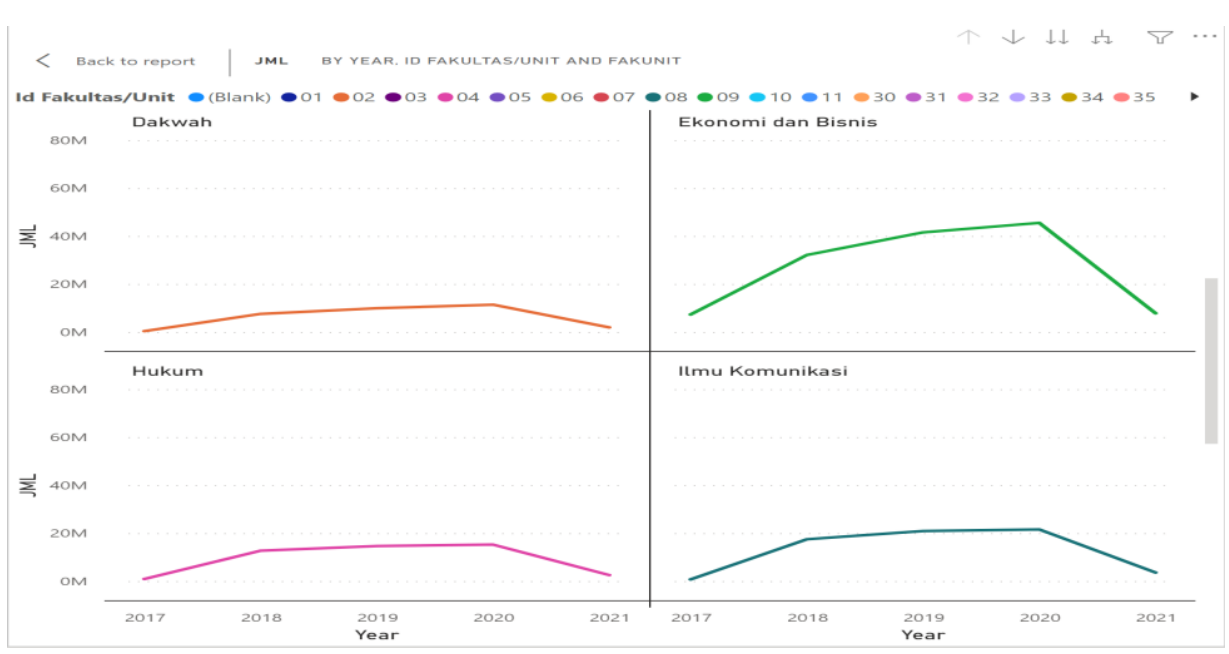

Gambar 11. Penerimaan internal by year and fakultas 2 


\subsubsection{Penyaluran ZIS BMU}

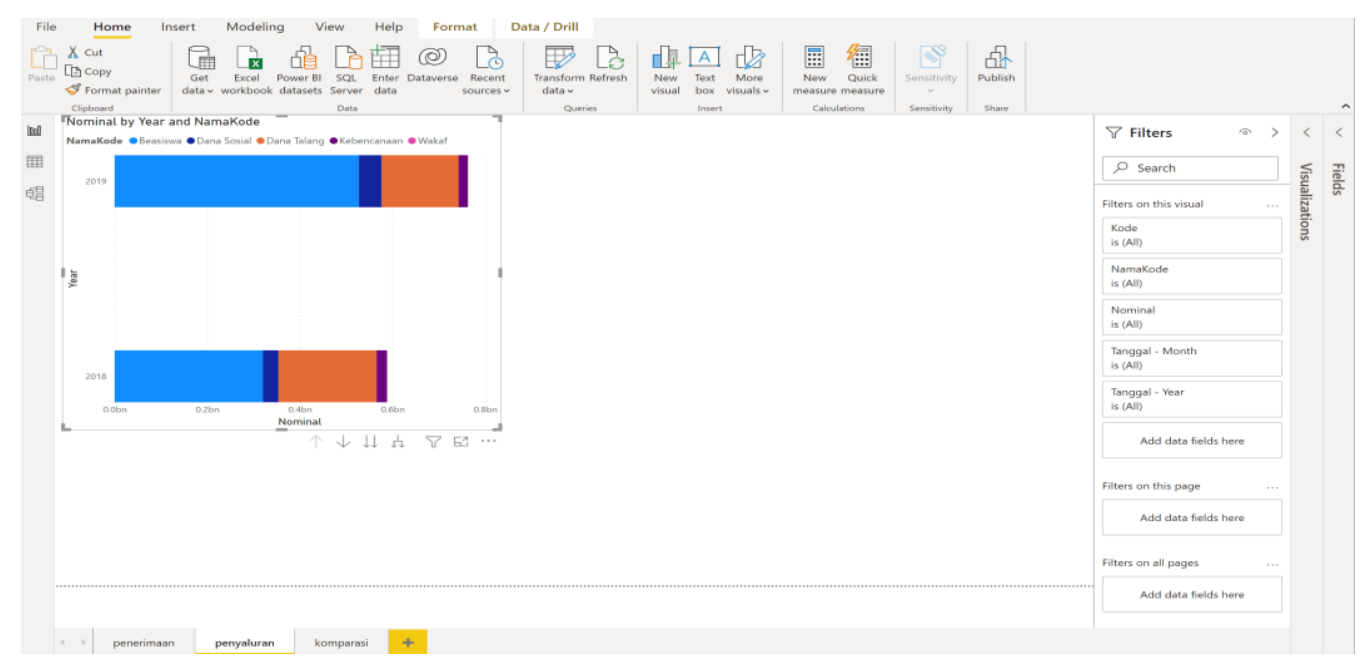

Gambar 12. Penyaluran ZIS by year and fakultas

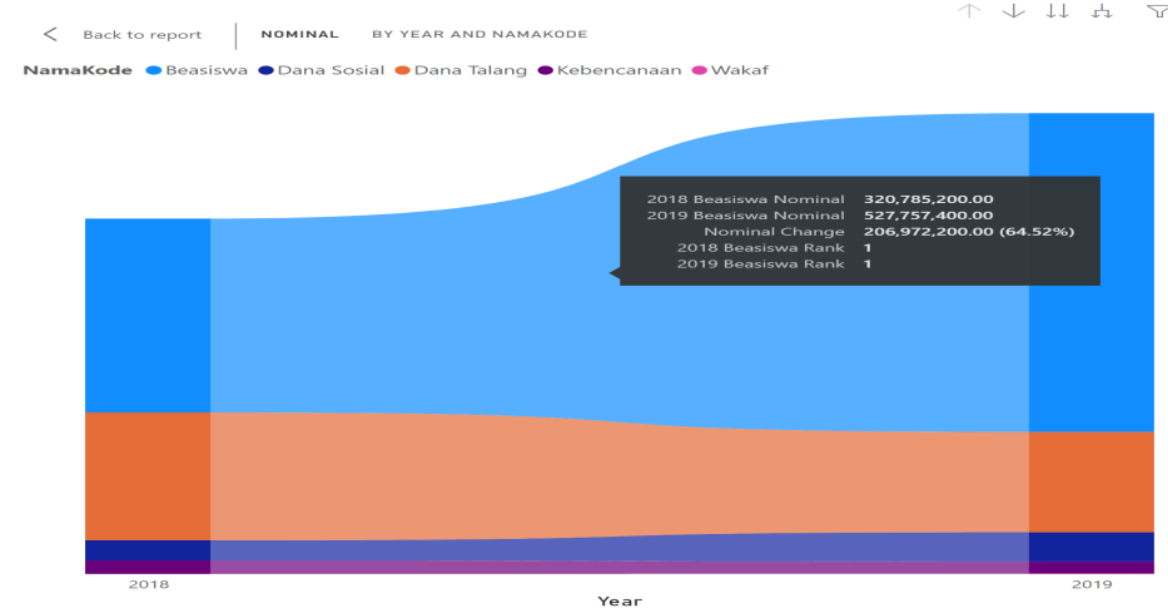

Gambar 13. Penyaluran ZIS by year and namakode 1

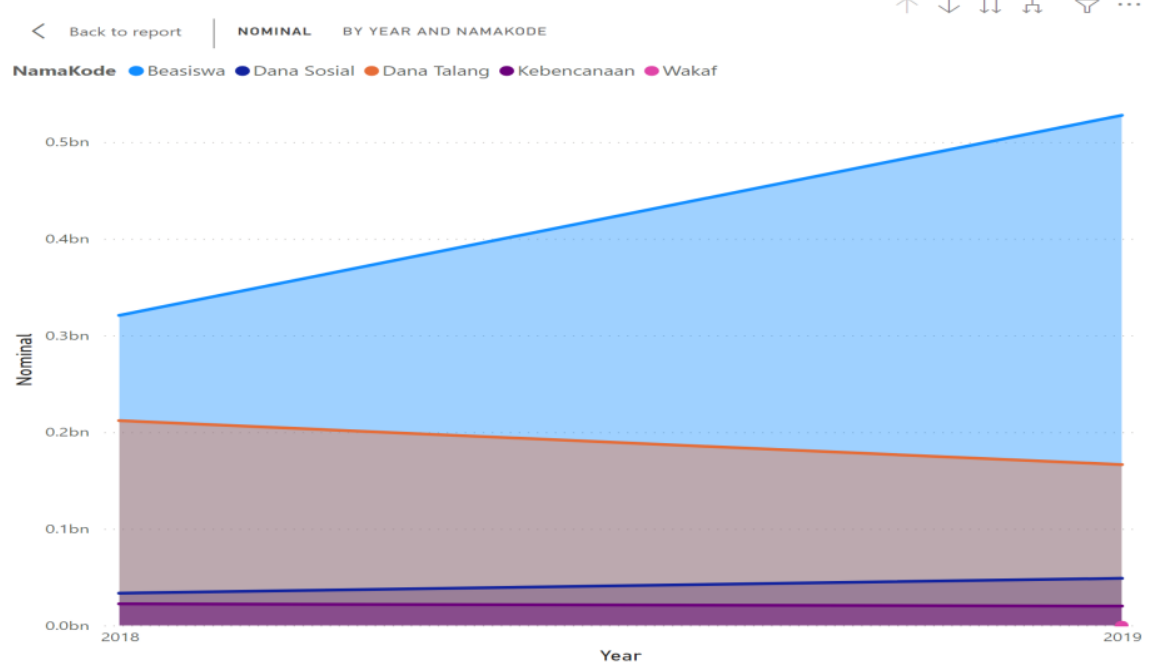

Gambar 14 . Penyaluran ZIS by year and namakode 2 


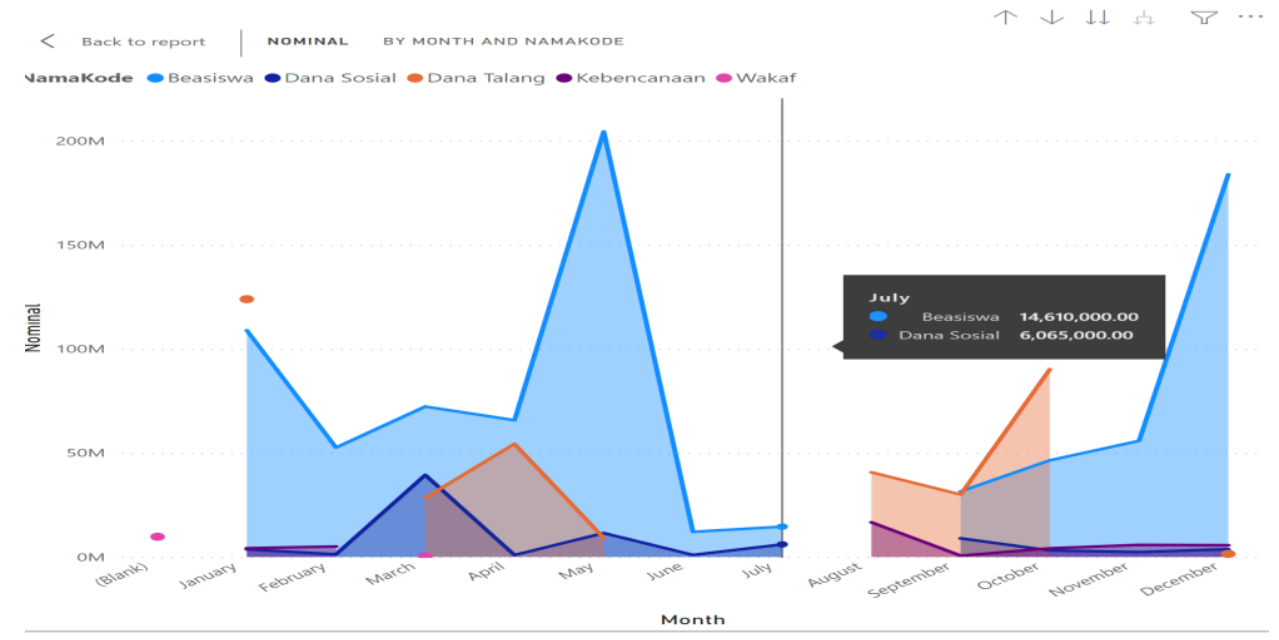

Gambar 15. Penyaluran ZIS by month/year and namakode - detail

\subsubsection{Analisis Hasil Pengembangan dan Implementasi Business Intelligence}

Hasil pengembangan dan implementasi BI menunjukkan bahwa BMU mampu meningkatkan kemampuan analitik berdasarkan data yang akurat dalam hal :

1. Penerimaan ZIS baik internal maupun eksternal, dengan membandingkan penerimaan ZIS berdasarkan waktu dan entitas pemberi ZIS, BMU memiliki kemampuan analitik untuk meningkatkan kinerja jumlah penerimaan ZIS.

2. Penyaluran ZIS untuk beasiswa, dana sosial, dana talang, kebencanaan dan wakaf, dengan membandingkan pengeluaran ZIS berdasarkan waktu, jenis ZIS, dan entitas penerima ZIS, BMU mampu melakukan analisis untuk meningkatkan kinerja jumlah penyaluran ZIS terutama beasiswa dan dana talang.

3. Pembayaran dana talang oleh peminjam, dengan membandingkan jumlah dana talang yang jatuh tempo pembayaran berdasarkan waktu dan entitas penerima, BMU mampu melakukan analisa untuk meningkatkan kinerja ketepatan waktu pembayaran dana talang oleh peminjam

4. Waktu proses pencairan penyaluran ZIS, dengan membandingkan waktu pengajuan dan waktu pencairan ZIS, BMU memiliki kemampuan untuk menganalisa kinerja waktu pencairan penyaluran ZIS.

\section{Kesimpulan}

Hasil pengembangan dan implementasi aplikasi Business Intelligence di Baitul Maal Unisba, baik dalam bentuk data dan datawarehouse yang terstruktur, maupun dashboard Business Intelligence mampu menunjukkan peningkatan kemampuan analitik BMU untuk meningkatkan kinerjanya, terutama dalam hal peningkatan penerimaan dan penyaluran ZIS, ketepatan waktu pembayaran dana talang oleh peminjam, dan waktu proses pencairan ZIS. Hal ini akan mampu meningkatkan kepercayaan pemberi ZIS terhadap Baitul Maal Unisba di masa yang akan datang, yang berarti semakin besarnya penyaluran ZIS baik untuk internal Unisba maupun masyarakat umum.

\section{Daftar Pustaka}

1. Baznas. Statistik Zakat Nasional 2017. Badan Amil Zakat Nasional; 2017. h iii.

2. Baznas. Statistik Zakat Nasional 2019. Badan Amil Zakat Nasional; 2019. h 42.

3. Junaedi, I., Abdillah, D., \& Yasin, V. (2020). Analisis Perancangan Dan Pembangunan Business Intelligence Penerimaan Negara Bukan Pajak Kementerian Keuangan RI. Journal Information System, Applied, Management, Accounting and Research, 4(3), 88-101. 
4. Larissa T. Moss, Shaku Atre. (2013). Business Intelligence Roadmap: The Complete Project Lifecycle for Decision Support Applications. Addison Wesley.

5. Martono, A., Sudarto, F., Rustiana, D., \& Rahayu, N. (2013). Rancang-Bangun Business Intelligence Pada Perpustakaan Sekolah Studi Kasus di SMP Negeri 1 Cisoka SEMNASTEKNOMEDIA ONLINE, 1(1), 18-33.

6. Steve,Williams. (2016). Business Intelligence Strategy and Big Data Analytics: A General Management Perspective. Elsevier Inc.

7. Sharda Ramesh, Dursun Delen, Efraim Turban. (2018). Business Intelligence, Analytics, and Data Science: A Managerial Perspective. 4th ed. Pearson.

8. Rouhani Saeed, Asgari Sara, Mirhosseni Vahid Seyed. (2021). Review Study: Business Intelligence Concepts and Approaches. American Journal of Scientific Research, Issue 50, pp.62-75. ISSN 1450$223 X$

9. Wiedr Berhnard, Ossimitz Luise Maria. (2015) .The impact of Business Intelligence on the quality of decision making - a mediation model. Elsevier Procedia Computer Science 64. 1163-1171.

10. Warnars, S. (2008). Rancangan Infrastruktur E-Bisnis Business Intelligence Pada Perguruan Tinggi. Telkomnika, 6, (2),, 115 - 124. 